\title{
Role of Insulin in the Intermediary Metabolism of the Activated Thymic-derived Lymphocyte
}

\author{
J. Harold Helderman, with the technical assistance of Linda Edwards, Renal \\ Immunology Laboratory, Renal Division, Department of Internal Medicine, \\ University of Texas Health Science Center at Dallas, Southwestern Medical \\ School, Dallas, Texas 75235
}

\begin{abstract}
A B S T R A C T The hypothesis that a role for insulin in the metabolism of $T$ cells would be evident after cell activation when receptors appear was tested to validate the $T$ cell model and to analyze the mechanism by which insulin may function in immunoregulation. Measuring the flux rates of 3-O-[methyl- $\left.{ }^{3} \mathrm{H}\right]-\mathrm{D}-$ glucose and aminoisobutyric acid, $\alpha-\left[1-{ }^{14} \mathrm{C}\right]$, lactate production and oxidation, and glucose oxidation from carbon 1and carbon 6-labeled substrates, it was determined that (a) mitogens such as phytohemagglutinin enhance basal $\mathrm{T}$ lymphocyte intermediary metabolism, (b) physiologic concentrations of insulin have no impact on the metabolism of unstimulated, cultured, receptornegative lymphocytes, and $(c)$ insulin provided to receptor bearing lymphocytes augments intermediary metabolism above mitogen stimulated levels. The importance of the pentose phosphate shunt pathway for energy metabolism in the stimulated lymphocyte was confirmed. These studies demonstrate that insulin has a classical physiologic role to play in the activated lymphocyte further validating the use of this cell to examine potential receptor defects in disorders of carbohydrate metabolism. By enhancing energy metabolism of stimulated lymphocytes, insulin serves biologic economy and thus may perform its immunoregulatory role.
\end{abstract}

\section{INTRODUCTION}

Insulin conveys its metabolic message to cells by means of a binding reaction to a membrane bound receptor protein. Determination of the characteristics of the insulin receptor and the mechanisms that control the expression of this receptor have advanced our knowledge of normal and abnormal physiology. To ex-

Presented in part at the National Meeting of The American Society for Clinical Investigation, Washington, D. C., 10-12 May 1980.

Received for publication 27 June 1980 and in revised form 26 January 1981. tend animal studies to man, it was desirable to discover receptor sites on cells that could be conveniently, repetitively, and safely obtained. Indeed, in a series of elegant studies, such receptor sites were characterized upon circulating cells that could then serve as "mirrors of cellular metabolism" (1-4). Initially, pains were taken to demonstrate that characteristics of insulin receptors on these circulating cells were identical to those existent for more traditional targets of the hormone. Additionally, circulating cells exhibited similar deviations from normal during experimental and pathophysiologic perturbation as that observed for target tissues. Nevertheless, the failure to readily measure a metabolic role for the hormone in these circulating cells has called the use of the circulating cell as a model of receptor alterations during disease into question. The resting lymphocyte, a circulating cell that has been used as such a model, does not bear insulin receptors in vivo (5). One should not perforce expect insulin to exert classical metabolic effects upon these resting, receptor-negative cells. This study was designed to validate the use of the activated lymphocyte model for the exploration of the pathogenesis of disorders of carbohydrate metabolism. It explores the hypothesis that insulin has a true biologic role in the lymphocyte which is revealed during cellular activation when an insulin receptor appears upon the membrane and is available for binding.

\section{METHODS}

Cell preparation. Lewis male rat spleens were teased through a sterile steel mesh into RPMI-1640 tissue culture medium (Microbiological Associates, Walkersville, Md.) buffered with $10 \mathrm{mM}$ Hepes and fortified with $5 \%$ (vol/vol) sterile, heat-inactivated, insulin-depleted $(<1.5 \mu \mathrm{U} / \mathrm{ml})$ fetal calf serum. Mononuclear leukocytes were collected from the interface of a Ficoll-Hypaque density gradient (specific gravity, 1.091) and washed twice. $T$ lymphocytes were obtained by passing these leukocytes over nylon wool columns prepared by the method of Handwerger and Schwartz (6) as described (5). Such cells were $>95 \% \mathrm{~T}$ pedigree as deter- 
mined by cell markers performed as described in part by Soulillou et al. (7) and by Helderman and Strom (5).

Cellular activation. Induction of insulin receptors was accomplished by activation of the T lymphocytes by co-culturing the cells with the mitogen phytohemagglutinin $\mathrm{P}$ (PHAP), ${ }^{1} 100 \mu \mathrm{g} / \mathrm{ml}$ (Difco Laboratories, Detroit, Mich.) (8-9). Cultures were established in RPMI-1640 media buffered with 10 $\mathrm{mM}$ Hepes and enriched with insulin-poor fetal calf serum for $48 \mathrm{~h}$ at $37^{\circ} \mathrm{C}$ in an atmosphere of $5 \% \mathrm{CO}_{2}$ and air. At the completion of the culture, the cells were harvested, washed, and analyzed for both insulin receptor binding and for the specific metabolic function under consideration.

Insulin binding assay. The basic assay technique, a modification of that described by Gammeltoft and Gliemann $(10,11)$, has been extensively described in a previous publication (5) and validated further in others $(9,12)$. The modification permits sedimentation of lymphocytes through phthalate oils at a density at which $97 \%$ of the lymphocytes are recovered in the pellet, whereas contamination of the pellet by free ligand is only $0.04 \%$ (12). As described in my previous studies, this technique determines both specific and nonspecific binding by virtue of competitive protein binding between [ ${ }^{125}$ I] iodoinsulin and unlabeled hormone. Specific binding ranged between 33 and $50 \%$ of the total in binding curves using physiologic concentrations of insulin. In the present studies an aliquot of lectin-treated, nylon woolfiltered, T-enriched cells were reserved for measurement of receptors to insure that the $\mathrm{PHA}$ exerted its usual and expected effect as a stimulus for lymphocyte insulin receptor generation. [ ${ }^{125}$ I] iodoinsulin binding to PHA-treated T lymphocytes was determined at $2 \mathrm{ng} / \mathrm{ml}$ (on the rapid portion of the association binding isotherm for this cell [5]) in the presence and absence of $4 \mu \mathrm{g} / \mathrm{ml}$ unlabeled insulin.

3-O- $\mathrm{CH}_{3}$ glucose transport. After the binding assay confirmed the presence of insulin receptors on PHA-treated cells and the absence of receptors on untreated, cultured cells (negative controls), the cell density was adjusted to $25 \times 10^{6} /$ $\mathrm{ml}$ in a buffered salt solution containing $90 \mathrm{mM} \mathrm{NaCl}, 8 \mathrm{mM}$ $\mathrm{KCl}, 0.4 \mathrm{mM} \mathrm{CaCl}{ }_{2} \cdot 6 \mathrm{H}_{2} \mathrm{O}, 0.4 \mathrm{mM} \mathrm{MgSO} \cdot \cdot 7 \mathrm{H}_{2} \mathrm{O}, 50 \mathrm{mM}$ 3-( $N$-morpholino) propane-sulfonic acid (CalbiochemBehring Corp., American Hoechst Corp., La Jolla, Calif.), 2 $\mathrm{mM} \mathrm{NaH} \mathrm{PO}_{4}, \mathrm{pH}$ 7.4. To determine the temporal relationships that govern transport, $100 \mu \mathrm{l}$ of the cultured cells at that concentration was placed into $12 \times 75-\mathrm{mm}$ glass tube containing $15 \mu \mathrm{l}$ of the buffer and $50 \mu \mathrm{l}$ of $3-\mathrm{O}-\left[\right.$ methyl $\left.{ }^{3} \mathrm{H}\right]$-D-glucose $(90 \mathrm{mCi} / \mathrm{mmol}$; New England Nuclear, Boston, Mass.) at a final concentration of $0.1 \mathrm{mM}$. The reaction was allowed to proceed at $37^{\circ} \mathrm{C}$ in a shaking water bath and stopped at various times by placing $150 \mu \mathrm{l}$ of the reaction mixture on a bed of phthalate oils in plastic microfuge tubes $(10: 1$ ratio of dibutyl to dinonyl), then centrifuging at $10,000 \mathrm{rpm}$ in a Beckman microfuge (Beckman Instruments, Inc., Fullerton, Calif.). The cell button was reserved by cutting the tip of the microfuge tube into a scintillation phial containing $3 \mathrm{ml}$ of fluor $500 \mathrm{ml}$ Triton X-100 in 15 liters of toluene containing PPO $10.5 \mathrm{~g}$ and POPOP $0.15 \mathrm{~g}$ ). This separation method allowed recovery of $>98 \%$ of the cells initially placed atop the oil with $<0.01 \%$ contamination of the oil by free isotope determined as described (12). To determine the effect of insulin on the flux rate of 3-O-[methyl $\left.{ }^{3} \mathrm{H}\right]-\mathrm{D}$-glucose, $100 \mu \mathrm{l}$ of cells at $25 \times 10^{6} /$ $\mathrm{ml}$ was studied in the presence of $1 \mathrm{nM}$ single peak porcine insulin (a kind gift of Dr. Ronald Chance, Eli Lilly \& Co., Indianapolis, Ind.) as a $15-\mu \mathrm{l}$ vol or in the absence of insulin (as $15 \mu$ l of buffer). The flux rate was determined from the

${ }^{1}$ Abbreviations used in this paper: AIB, aminoisobutyric acid; PHA, phytohemagglutinin. slope of the rapid phase of the transport time-course with the reaction stopped by immersion of the tubes in ice at $0,0.5,1$, $1.5,2$, and $3 \mathrm{~min}$ after the addition of tracer. The slope was calculated using a least squares fit of data obtained at those times. To be acceptable the regression coefficient had to indicate a linear fit was statistically best at the $95 \%$ confidence level.

$\mathrm{CO}_{2}$ production from lactate or glucose substrates. The production of $\mathrm{CO}_{2}$ from glucose substrates by rat splenic $\mathrm{T}$ lymphocytes was measured by a modification of the method of MacLennan and Golstein (13). The PHA-treated, insulin receptor-bearing or the untreated, receptor-negative control $\mathrm{T}$ cells were each placed at $5 \times 10^{7} / \mathrm{ml}$ in low phosphate-buffered saline $\left(\mathrm{NaCl} 137 \mathrm{mM}\right.$, KCl $1.5 \mathrm{mM}, \mathrm{K}_{2} \mathrm{HPO}_{4} 1.5 \mathrm{mM}$, $\mathrm{Na}_{2} \mathrm{HPO}_{4} 3.2 \mathrm{mM}, \mathrm{CaCl}_{2} 1 \mathrm{mM}, \mathrm{MgCl}_{2} \cdot 6 \mathrm{H}_{2} \mathrm{O} 0.5 \mathrm{mM}, \mathrm{pH} 7.4$ enriched with $1.0 \%$ five times recrystallized bovine serum albumin). $100 \mu \mathrm{l}$ of the cells was placed into borosilicate glass culture tubes, $6 \times 50 \mathrm{~mm}$ (Kimble Div., Owens-Illinois, Inc., Toledo, Ohio) cut so that they could be lowered into standard scintillation phials. To the culture tubes were added $10 \mu \mathrm{l}$ of buffer or single peak insulin (final concentration 10-0.1 $\mathrm{nM}), 5 \mu \mathrm{l}$ of either $\mathrm{D}-\left[1-{ }^{14} \mathrm{C}\right] \mathrm{glucose}(7.16 \mathrm{mCi} / \mathrm{mmol})$ or $\mathrm{D}$ $\left[6-{ }^{14} \mathrm{C}\right]$ glucose $(10.6 \mathrm{mCi} / \mathrm{mmol}$ ) (New England Nuclear) the stock so diluted with buffer to contain $0.025 \mu \mathrm{Ci}$, and $10 \mu \mathrm{l}$ cold glucose (final concentration $5 \mathrm{mM}$ ). The scintillation phials containing the culture tubes with the reaction mixture were sealed with rubber caps (Kontes Co., Vineland, N. J.). The mixture was then incubated at $37^{\circ} \mathrm{C}$ for $1 \mathrm{~h}$, after which $200 \mu \mathrm{l}$ hyamine hydroxide was injected through the rubber seal into the phial outside the culture tube, followed by the injection of $100 \mu \mathrm{l}$ of $30 \%$ perchloric acid directly into the culture tube. The phials were then incubated for another hour at $37^{\circ} \mathrm{C}$ in a shaking water bath to permit the $\mathrm{CO}_{2}$ produced in the reaction to be trapped by the hyamine. The rubber seal was removed, the culture tube was discarded, $10 \mathrm{ml}$ of fluor was added to the phials, and the phials were counted in a liquid spectrophotometer. $\mathrm{CO}_{2}$ production from carbon 1labeled and carbon 6-labeled substrates was estimated by multiplying the counts per minute trapped by the specific activity of the added radiolabeled glucose determined for each run. MacLennan and Golstein (13) have demonstrated that recycling of label represents a minor or trivial error when these assay conditions are used. Therefore, no attempts were made to correct the data for metabolic recycling of glucose through the pentose phosphate cycle.

To measure the oxidation of lactate to $\mathrm{CO}_{2}$, a similar assay was employed substituting $5 \mu$ l lactic acid, D- $\left[1-{ }^{14} \mathrm{C}\right]$ lactate (18.6 $\mathrm{mCi} / \mathrm{mmol}$; New England Nuclear), at a final concentration of $1 \mu \mathrm{M}$, for the labeled glucose.

Lactate production. Lymphocytes prepared as described were cultured with or without $100 \mu \mathrm{g} / \mathrm{ml}$ PHA-P. The resultant cells were tested for the presence of insulin receptors to confirm the expected effect of the lectin treatment. $5 \times 10^{6}$ cells in $1 \mathrm{ml}$ of RPMI-1640, $10 \mathrm{mM}$ Hepes, $0.1 \%$ bovine serum albumin were placed in $12 \times 75-\mathrm{mm}$ glass tubes to which was added $10 \mu \mathrm{l}$ of insulin (final concentration ranging from 10 to 0.1 $\mathrm{nM}$ ). The reaction mixture was incubated for $10 \mathrm{~min}$ at $37^{\circ} \mathrm{C}$ in a shaking water bath and the reaction stopped by the addition of perchloric acid to make a final $2 \%$ solution ( $\mathrm{vol} / \mathrm{vol}$ ) in a vol of $1.5 \mathrm{ml}$. The tubes were centrifuged at $2,600 \mathrm{rpm}$ in a Sorvall centrifuge (Dupont Instruments - Sorvall Biomedical Div. Newtown Conn.) swinging bucket rotor $\mathrm{HL}-82 \mathrm{~min}$ at $4^{\circ} \mathrm{C}$. The supernate was brought to $\mathrm{pH} 7$ by the addition of $20 \%$ $\mathrm{KOH}$ and centrifuged again in the cold. The measurement of lactate depends upon the oxidation of the lactate in the sample to pyruvate in the presence of the enzyme lactic dehydrogenase and $\beta$-NAD. The conversion of the $\beta$-NAD to $\beta$-NADH occurs as a molar equivalent of the lactate oxidized. $0.1-\mathrm{ml}$ 
aliquots of the neutralized supernate were added to $0.9 \mathrm{ml}$ of a reaction mixture that included $5 \mu$ l lactate dehydrogenase (Boehringer Mannheim Biochemicals, Indianapolis, Ind.), one part 1 M Tris, pH 8.5, two parts $\beta$-NAD (Signa Chemical Co., St. Louis, Mo.), three parts hydrazine $(0.5 \mathrm{ml}$ hydrazine hydrate $+0.625 \mathrm{ml} 4 \mathrm{~N} \mathrm{HCl}$ to $10 \mathrm{ml}$ water), and three parts water. A second set of aliquots were added to the same reaction mixture devoid of the lactate dehydrogenase to measure the $\beta$ $\mathrm{NADH}$ present before the oxidation was begun. Samples were vortexed and then incubated $80 \mathrm{~min}$ at $24^{\circ} \mathrm{C}$. The optical density of all samples was determined at $340 \mathrm{~nm}$ in $1 \mathrm{~cm}$ cuvettes and lactate was determined using the molar extinction coefficient for $\beta$-NADH. [(Optical density in the presence of enzyme - optical density with no enzyme) (0.161) $($ dilution $)=$ millimolar lactate $]$. All determinations represent the mean of triplicate assays.

Aminoisobutyric acid transport. Cells prepared and treated with lectin as above were placed at $12.5 \times 10^{6}$ lymphocytes/ml in Hanks' balanced salt solution (Microbiological Associates) $-0.1 \%$ bovine serum albumin. $160 \mu \mathrm{l}$ of the cell mixture was placed in $12 \times 75-\mathrm{mm}$ glass test tubes to which $20 \mu \mathrm{l}$ media or insulin was added (final concentration $1 \mathrm{nM}$ ) and incubated at $37^{\circ} \mathrm{C}$ in a shaking water bath for $10 \mathrm{~min}$, a time determined in pilot experiments to provide maximal insulin effect. $20 \mu l \alpha-\left[1-{ }^{14} \mathrm{C}\right]$ aminoisobutyric acid (AIB), $(51.6 \mathrm{mCi} / \mathrm{mmol}$ ) (New England Nuclear) was added to make a final concentration of $95 \mu \mathrm{M}$. The tubes were then incubated further for times varying over $75 \mathrm{~min}$. The transport reaction was stopped by the addition of $2 \mathrm{ml}$ of ice cold Hanks' balanced salt solution followed by a 2 -min spin at $2,000 \mathrm{rpm}$ at $4^{\circ} \mathrm{C}$ in the Sorvall centrifuge. The cells were washed twice in ice-cold media and the intracellular AIB was obtained by hypotonic $(0.5 \mathrm{ml}$ water $)$ and freeze-thaw lysis of the final cell pellet. Cell debris was removed by another 2,000 rpm spin at $4^{\circ} \mathrm{C}$. The supernate was decanted into $10 \mathrm{ml}$ of fluor $(40 \mathrm{ml}$ Permafluor I, Packard Instrument Co., Downers Grove, Ill.; 1 liter toluene; and $100 \mathrm{ml}$ BioSolv, Beckman Instruments Inc.) and counted in a liquid spectrophotometer.

\section{RESULTS}

Insulin binding. Cells for the various metabolic studies were used only when the expected lectin-induced insulin receptor generation was observed. Using $2 \mathrm{ng} / \mathrm{ml}$ [ $\left.{ }^{125} \mathrm{I}\right]$ iodoinsulin as ligand, $3.21 \pm 0.13 \mathrm{pg}$ (mean \pm SEM) were specifically bound to $10^{6} \mathrm{~T}$ cells after $48 \mathrm{~h}$ incubation with PHA ( $100 \mu \mathrm{g} / \mathrm{ml})$, binding comparable to that observed in our studies that first characterized the effects of this lectin with respect to the $T$ lymphocyte insulin receptor $(8,9)$. The untreated cells had $0.07 \pm 0.03 \mathrm{pg} / 10^{6}$ bound, well below the detectable positive binding limit obtained in our assay ( $\geqq 0.8 \mathrm{pg} /$ $\left.10^{6}\right)$. These data demonstrated that lectin-treated $\mathrm{T}$ cells were insulin receptor-bearing cells and that untreated, cultured cells were receptor-negative, thus serving as controls.

3-O-methyl glucose transport. Time-course experiments $(n=4$, Fig. 1$)$ demonstrated that uptake equilibrium was reached between 10 and $15 \mathrm{~min}$ after presentation of the labeled 3-O-methyl glucose to the cells. PHA-stimulated, receptor-bearing $\mathrm{T}$ cells had a greater flux than was present in the basal culture untreated with lectin, as indicated by the comparison of

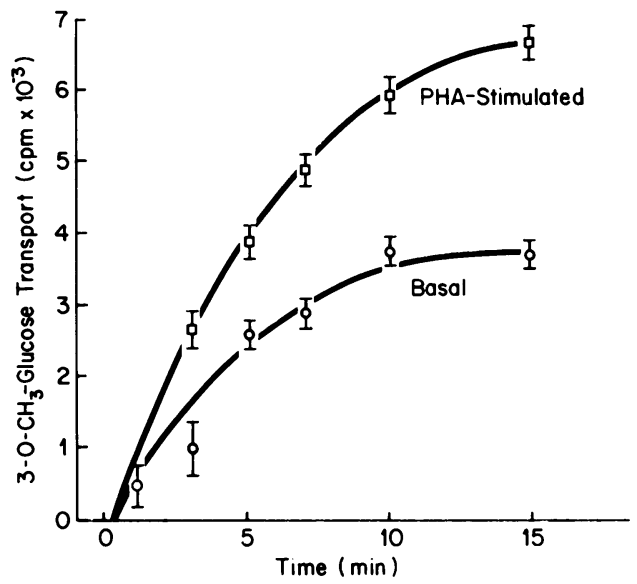

Figure 1 The time-course of 3-O-[methyl- $\left.{ }^{3} \mathrm{H}\right]-\mathrm{D}$-glucose transport into $\mathrm{T}$ cells. Basal transport reflects data obtained from $T$ cells carried in culture in enriched media without PHA. Such cells do not bear insulin receptors. PHA-stimulated cells are $\mathrm{T}$ cells studied after treatment with $100 \mu \mathrm{g} / \mathrm{ml}$ PHA-P for $48 \mathrm{~h}$ at $37^{\circ} \mathrm{C}$ and are insulin receptor positive.

the slopes of the uptake in Fig. 1. The flux difference and the effect of a physiologic concentration of insulin on the flux rates of glucose into lectin-treated and control cells were evaluated by determining the slope of the rapid phase of the time-course for each condition. Basal flux was $3.14 \pm 0.52 \mathrm{fm} / 10^{6}$ cells $\cdot \min (n=7$ for all studies). PHA treatment significantly increased the basal flux rate to $5.22 \pm 0.76 \mathrm{fm} / 10^{6} \cdot \min (P<0.05$ by paired $t$ test analysis). Although addition of $1 \mathrm{nM}$ single peak insulin did not alter glucose flux rates in the insulin receptor-negative control cells $\left(3.29 \pm 0.57 \mathrm{fm} / 10^{6}\right.$ cells $\cdot \min )$, one observed a significant enhancement of flux when $1 \mathrm{nM}$ insulin was provided to PHA-treated, receptor-bearing cells. In this group the basal flux of $5.22 \mathrm{fm} / 10^{6} \cdot \mathrm{min}$ was increased to $8.44 \pm 1.2(P<0.02$, paired $t$ test). Several prototypic conclusions flow from these data. First, mitogen stimulation itself enhanced glucose transport. Second, insulin produced no added stimulation of transport in T cells that do not bear insulin receptors. Third, insulin, in a dose-dependent manner, enhanced the stimulated glucose transport rate in $T$ cells that do carry insulin receptors.

Glucose oxidation. The insulin effect on T lymphocyte oxidation of glucose was evaluated by measuring the amount of labeled $\mathrm{CO}_{2}$ released from cells provided either $\mathrm{D}-6-{ }^{14} \mathrm{C}$ - or $\mathrm{D}-1-{ }^{14} \mathrm{C}$-labeled glucose substrates. PHA treatment alone provided a stimulus for enhanced glucose oxidation from the substrate labeled in the 6 position, the rate of conversion increasing from 0.027 \pm 0.007 to $0.071 \pm 0.018 \mathrm{nmol} / 10^{6}$ cells $\cdot \mathrm{h}(n=7 ; P$ $<0.05)$ (Fig. 2A). Insulin did not increase glucose oxidation from the carbon 6-labeled substrate in the insulin receptor-negative $\mathrm{T}$ cells in a statistically significant manner (paired $t$ test). Although there appears to be an 


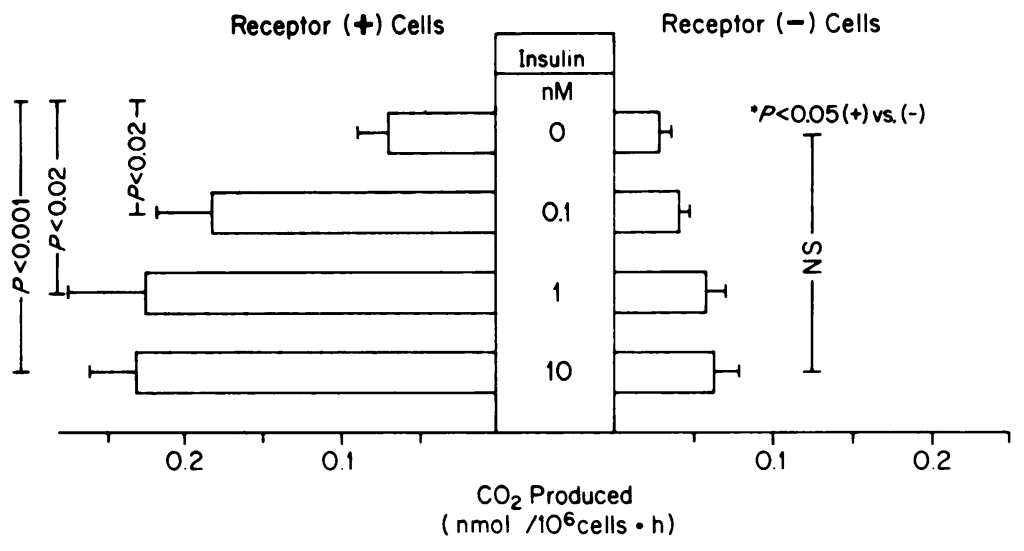

B

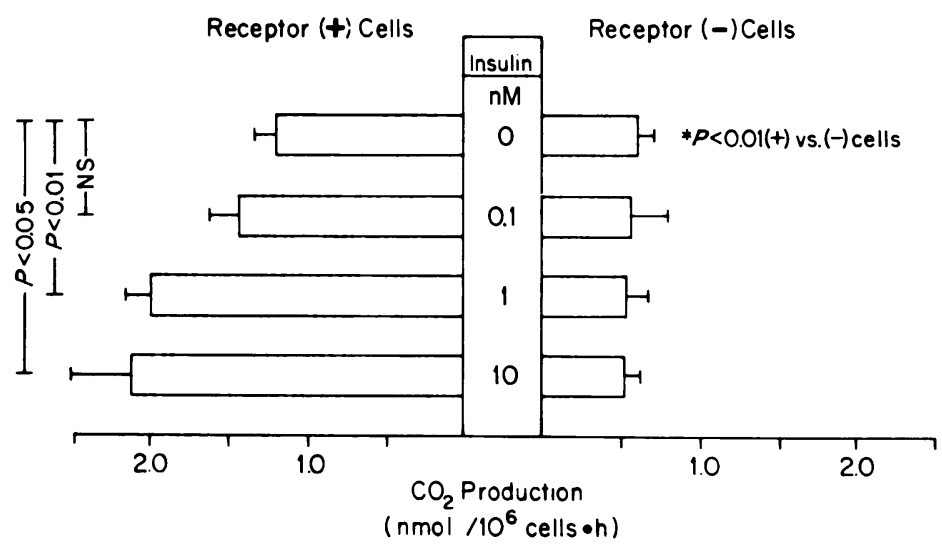

FIGURE 2 (A) Formation of $\left[{ }^{14} \mathrm{C}\right] \mathrm{O}_{2}$ from $\mathrm{D}-\left[6-{ }^{14} \mathrm{C}\right]$ glucose as affected by insulin in $\mathrm{T}$ cells. The left set of bars depicts $\mathrm{CO}_{2}$ production in $\mathrm{nmol} / 10^{6}$ cells $\cdot h$ from cells cultured with 100 $\mu \mathrm{g} / \mathrm{ml}$ PHA-P for $48 \mathrm{~h}$ at $37^{\circ} \mathrm{C}$ and are insulin receptor positive. The right set of bars depicts production in cells carried in culture without lectin stimulation that are receptor negative. For each set of seven studies single peak insulin was added to $5 \times 10^{6}$ lymphocytes in the presence of $0.025 \mu \mathrm{Ci}$ of tracer and $5 \mathrm{mM}$ cold glucose. (B) Formation of $\left[{ }^{14} \mathrm{C}\right] \mathrm{O}_{2}$ from $\mathrm{D}-\left[1-{ }^{14} \mathrm{C}\right] \mathrm{glucose}$ as affected by insulin in $\mathrm{T}$ cells. The experimental protocol was similar to that used to examine oxidation from the carbon 6-labeled substrate.

insulin-directed increase in these control cells the change was small $\left(0.027 \pm 0.007 \mathrm{nmol} / 10^{6} \cdot \mathrm{h}\right.$ with no preincubation with insulin as compared to $0.061 \pm 0.018$ at $0.1 \mathrm{nM}$ insulin) and not significant. In marked contrast was the insulin effect on receptor-positive $T$ cells (Fig. 2A). In these studies, a dose-directed augmentation of glucose oxidation was observed with a maximal oxidation rate of $0.233 \pm 0.027 \mathrm{nmol} / 10^{6} \cdot \mathrm{h}$.

Similar relationships between lectin activation and insulin augmentation were observed when $T$ lymphocytes were provided substrate labeled on the first carbon of the glucose skeleton (Fig. 2B). For these studies, mitogen treatment stimulated basal oxidation rates from $0.60 \pm 0.10$ to $1.19 \pm 0.15 \mathrm{nmol} / 10^{6} \cdot \mathrm{h}(n=5$; $P<0.01$ ); insulin exerted no enhancing effect for oxidation in insulin receptor-negative cells, while strongly increasing oxidation in receptor-bearing $\mathrm{T}$ cells. Note that $\mathrm{CO}_{2}$ formation from the carbon 1-labeled substrate is an order of magnitude greater than that observed from $\mathrm{D}-6-{ }^{14} \mathrm{C}$, an observation similar to that of MacLennan and Golstein (13).

Lactate production and oxidation. Insulin supported lactate production was examined in six experiments performed in cells with and without the insulin receptor (Fig. 3). Similar to each metabolic function reported above, mitogen treatment alone stimulated lac- 


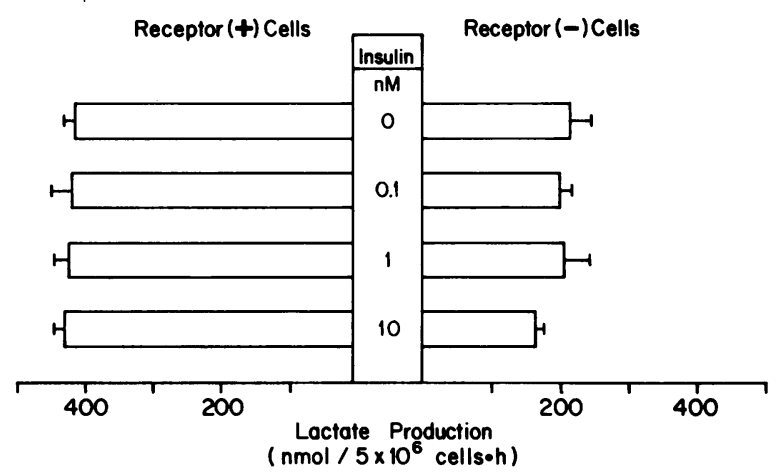

FIGURE 3 Insulin effect on T lymphocyte lactate levels in cells with and without insulin receptors. $5 \times 10^{6}$ lymphocytes in $1 \mathrm{ml}$ of media were treated with single peak insulin for 10 min at $37^{\circ} \mathrm{C}$. Lactate produced was determined by measuring the conversion of $\beta$-NAD to $\beta$-NADH during the oxidation of lactate to pyruvate.

tate formation almost twofold over control, cultured $\mathrm{T}$ cell rates $\left(215 \pm 35 \mathrm{nmol} / 5 \times 10^{6}\right.$ cells $\cdot h$ compared with $413 \pm 15 ; P<0.001)$. In sharp distinction to the insulin effect observed for the previously detailed metabolic functions, insulin did not increase further lactate concentrations in insulin receptor-bearing $T$ lymphocytes.

To examine further the insulin effect on lactate metabolism in the $\mathrm{T}$ cell, lactate oxidation to $\mathrm{CO}_{2}$ was estimated by the conversion of $\mathrm{D}-\left[1-{ }^{14} \mathrm{C}\right]$ lactate to $\left[{ }^{14} \mathrm{C} \mathrm{O}_{2}\right.$. The data in Fig. 4 demonstrate that lectin treatment alone enhanced $\mathrm{CO}_{2}$ formation, insulin did not augment lactate oxidation in receptor negative cells, but markedly increased oxidation in a dose response fashion in receptor-positive cells (maximal rate of conversion, $18 \pm 3 \mathrm{pmol} / 2 \times 10^{6}$ cells $\cdot h$ ). In contrast to the effect of insulin on lactate levels at a given point in time, the hormone exerted the by now expected re-

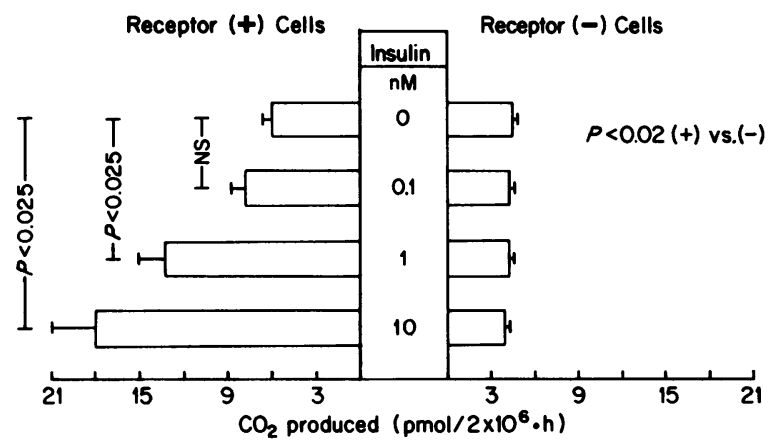

Figure 4 Insulin effect on conversion of lactate to $\mathrm{CO}_{2}$ in T lymphocytes. The left set of bars represent insulin receptor positive cells after treatment with PHA-P and the right set untreated receptor negative cells. These studies were performed in a similar manner to those described in Fig. 2A with the substitution of $\mathrm{D}-\left[1{ }^{14} \mathrm{C}\right]$ lactate at a final concentration of $1 \mu \mathrm{M}$ for the labeled glucose. sponse for lymphocyte lactate oxidation in receptorbearing $\mathrm{T}$ cells.

AIB transport. The ability of insulin to augment $\mathrm{T}$ lymphocyte transport of the index amino acid, AIB was studied in seven sets of cultures with and without lectin treatment. Since the time-course of AIB uptake into splenic $T$ lymphocytes resembled that of Wise $(14,15)$, AIB flux was calculated in the same manner using the slope of the rapid portion of this time-course (0-20 min) with points obtained at $0,5,15$, and $20 \mathrm{~min}$. AIB flux was $3.3 \pm 0.7 \mathrm{pmol} / 2 \times 10^{6}$ cells $\cdot \min$ into PHA-treated cells which was enhanced over receptor-negative control cell flux, $1.9 \pm 0.3 \mathrm{pmol} / 2 \times 10^{6}$ cells $\cdot \min (n=7$, $P<0.02$ by paired $t$ test). Insulin at $1 \mathrm{nM}$ further enhanced AIB transport only in receptor-positive cells $\left(4.4 \pm 0.6 \mathrm{pmol} / 2 \times 10^{6} \mathrm{cells} \cdot \min , P<0.025\right.$ by paired $t$ test), but the magnitude of the increase in transport was small. Enhancement to nearly $25 \%$ at $1 \mathrm{nM}$ insulin was similar to that observed by Goldfine (16) for thymocytes at this concentration of insulin. A dose-response relationship in the physiologic range was not observed for this metabolic function.

\section{DISCUSSION}

These studies explored the concept that insulin has a role in support of $T$ lymphocyte intermediary metabolism revealed when the cell is activated and bears an insulin receptor. The model used to pursue this exploration was that of the lectin activated $T$ cell. Lectin treatment has been shown previously and confirmed in these studies to provide the necessary stimulus for $T$ cell insulin receptor generation $(8,9)$. Several conclusions are clear from the various data presented in this manuscript. First, lectin activation enhances basal intermediary metabolism of T cells. Second, physiologic concentrations of insulin have no impact on the metabolism of unstimulated cultured cells that do not bear insulin receptors. This observation confirms the previously held conclusion that insulin has no classical biologic activity in freshly prepared mononuclear cells $(17-20)$. Third, insulin supplied to the activated $\mathrm{T}$ lymphocyte carrying a normal complement of insulin receptors is fully capable of augmenting glucose transport, glucose oxidation, lactate oxidation, and amino acid transport beyond the stimulation provided by the lectin treatment alone. Thus, insulin has a role in $\mathrm{T}$ cell intermediary metabolism only when the insulin receptor is present. These data allow support for the continued use of at least this circulating mononuclear cell to mirror insulin receptor characteristics present on tissues that are classically targets for insulin and a formulation of the potential mechanism by which insulin functions as an immunoregulatory molecule.

These metabolic studies in the lymphocyte ought to be placed into the perspective of the corpus of previous work in the field. With respect to glucose transport, 
these data display a similar time-course relationship to that found for a range of stimulated and unstimulated lymphoid tissues (21-24) and confirm the well described effects of PHA $(23,25,26)$. The role of insulin on glucose transport in receptor negative cells was explored by Hadden and co-workers (27) who reported an augmentation only when pharmalogic doses were used over time. That physiologic concentrations ( 100 $\mu \mathrm{U} / \mathrm{ml}$ for $4 \mathrm{~h}$ ) failed to enhance transport supports the conclusion that insulin exerts this classical biologic function only on receptor-bearing $\mathrm{T}$ cells.

The failure to observe an insulin effect on glucose use in freshly prepared lymphoid tissues is consonant with the bulk of previous work $(17,19,20,28,29)$ although Hofert and Phillips (30), using pharmacologic doses of insulin adequate to engage other membrane receptors capable of metabolic effect (31), did find a small but delayed insulin effect. The studies here show enhanced glucose use through both the tricarboxylic acid and pentose phosphate shunt pathways only in receptor bearing, immune activated lymphocytes lending further support to the permissive role of insulin in stimulated lymphocyte intermediary metabolism. Using carbon 1- and carbon 6-labeled substrates as estimates of the contribution of the TCA and pentose phosphate shunt pathways (32), we confirmed the recent observations of MacLennan and Goldstein, demonstrating here that mitogens as well as alloantigens increase $\mathrm{CO}_{2}$ formation with a preference for the latter pathway (13).

Insulin at physiologic concentrations also produces increased transport rates of amino acids as reflected by transport of AIB. Although basal- and lectin-stimulated rates of AIB transport observed here are similar to previous studies (33), we could not confirm an augmented rate after insulin administration to adult rodent splenocyte or in other lymphoid tissues (unpublished observations, 20) as found by Goldfine et al. (16). The latter found in thymocytes prepared from suckling rats, a small but significantly increased rate of transport after provision of $1 \mathrm{nM}$ insulin, with peak effects at a dose three orders of magnitude higher. In these neonatal animals, freshly prepared thymocytes may contain immature, receptor-bearing cells as part of the cellular population, cells that might be responsive to insulin. In experiments not shown here, when superphysiologic concentrations of insulin were presented to $T$ lymphocytes, AIB transport was stimulated much beyond the level found at the nanomolar dose suggesting that insulin may support AIB transport in lymphoid tissue through indirect as well as direct, receptor-related mechanisms.

In contrast to the insulin-directed alterations in the rate of intermediary metabolism of the $\mathrm{T}$ cell that have been defined and discussed to this point was the failure to identify insulin effects on lactate concentrations.
Lymphocyte lactate concentrations were markedly increased by cellular activation alone so that maximal levels might already have been achieved. On the other hand, the measurement of static lactate levels is a balance of synthesis, degradation, and oxidation to pyruvate. Therefore the effect of insulin on net lactate oxidation to $\mathrm{CO}_{2}$ was examined. The augmentation of $\mathrm{CO}_{2}$ formation from the lactate substrate induced by insulin in the activated cell may provide a partial explanation for the stable albeit elevated lactate levels with the addition of hormone to receptor-bearing cells. Insulin could have increased lactate formation directly (or indirectly through provision of increased substrate); enhancement of oxidation of lactate might have balanced the increased rate of formation so that no net change above lectin activated formation rates was observed.

Finally, I would like to discuss possible immunologic consequences that might flow from the demonstration that insulin exhibits an important role for lymphocyte intermediary metabolism only when an insulin receptor is present on an activated cell. Recently it has become clear that insulin participates in hormonal immunoregulation $(5,34)$. The $T$ lymphocyte can become an immune effector, a cytotoxic lymphocyte, or an accessory cell in grading direct responses of other $T$ cells or B cells. During this process the cell attains an insulin receptor that permits, only when present, insulin to alter at least the cytotoxic responses of that cell $(9,35)$. These studies expand the understanding of potential mechanisms whereby insulin serves as an immunoregulator in that these activated receptor-bearing $\mathrm{T}$ cells are poised to permit ambient insulin concentrations to augment intermediary metabolism to meet the energy demands of the responding lymphocyte to stimulus. Although insulin may not be an absolute requirement for $\mathrm{T}$ cell effector of function, these studies demonstrate the manner in which insulin plays a classical physiological role in the activated, responsive, receptor-bearing $\mathrm{T}$ lymphocyte that permits the hormone to serve biologic economy.

\section{ACKNOWLEDGMENTS}

I would like to thank Ms. Serena Buckner, Yvonne Wilburn, and Kay Stanley for patient preparation of the manuscript. Special recognition is due Juha Kokko for emphasizing the importance of these studies and to Morley Hollenberg who suggested the direction of this work. I am profoundly appreciative of the encouragement of my mentor and colleague Terry B. Strom.

This research was supported in part by National Institutes of Health grant AM-22510 and a grant from the American Diabetes Association, Inc.

\section{REFERENCES}

1. Gavin, J. R., III, P. Gorden, J. Roth, J. A. Archer, and D. N. Buell. 1973. Characteristics of the human lymphocyte insulin receptor. J. Biol. Chem. 218: 2202-2207. 
2. Gavin, J. R., III, J. Roth, P. Jen, and P. Freychet. 1972. Proc. Natl. Acad. Sci. U. S. A. 69: 747-751.

3. Olefsky, J., and G. Reaven. 1974. The human lymphocyte: a model for the study of insulin receptor interaction. J. Clin. Endocrinol. Metab. 38: 554-560.

4. Soll, A. H., J. D. Goldfine, J. Roth, and C. R. Kahn. 1974. Thymic lymphocytes in obese (ob/ob)mice. A mirror of the insulin receptor defect in liver and fat. J. Biol. Chem. 249: 4127-4131.

5. Helderman, J. H., and T. B. Strom. 1977. Emergence of insulin receptors upon alloimmune $\mathrm{T}$ cells in the rat. $J$. Clin. Invest. 59:338-344.

6. Handwerger, B. S., and R. H. Schwartz. 1974. Separation of murine lymphoid cells using nylon wool columns. Recovery of the B cell-enriched population. Transplantation (Baltimore). 18:544-547.

7. Soulillou, J. P., C. B. Carpenter, A. J. F. d'Apice, and T. B. Strom. 1976. The role of nonclassical, Fc-receptor-associated, Ag-B antigens (Ia) in rat allograft enhancement. $J$. Exp. Med. 43: 405-421.

8. Helderman, J. H., and T. B. Strom. 1978. Specific insulin binding site on $\mathrm{T}$ and $\mathrm{B}$ lymphocytes as a marker of cell activation. Nature (Lond.). 247: 62-63.

9. Helderman, J. H., T. C. Reynolds, and T. B. Strom. 1978. The insulin receptor as a universal marker of activated lymphocytes. Eur. J. Immunol. 8: 589-595.

10. Gammeltoft, S., and J. Gliemann. 1973. Binding and degradation of ${ }^{125}$ I-labelled insulin by isolated rat fat cells. Biochim. Biophys. Acta. 320: 16-32.

11. Gliemann, J., K. Фsterlind, J. Vinten, and S. Gammeltoft. 1972. A procedure for measurement of distribution spaces in isolated fat cells. Biochim. Biophys. Acta. 286: 1-9.

12. Helderman, J. H., and T. B. Strom. 1979. Role of protein and RNA synthesis in the development of insulin binding sites on activated thymus-derived lymphocytes. J. Biol. Chem. 254: 7203-7207.

13. MacLennan, I. C. M., and P. Golstein. 1978. Requirement for hexose, unrelated to energy provision, in T-cell mediated cytolysis at the lethal hit stage. J. Exp. Med. 147: $1551-1567$.

14. Wise, W. C. 1976. Maturation of membrane function: transport of amino acid by rat erythroid cells. J. Cell. Physiol. 87: 199-212.

15. Wise, W. C. 1979. Amino acid transport in thymic- and spleen-derived lymphocytes. J. Cell. Physiol. 97: $161-168$.

16. Goldfine, I. D., J. D. Gardner, and D. M. Neville, Jr. 1972. Insulin action in isolated rat thymocytes. I. binding of ${ }^{125} \mathrm{I}$-insulin and stimulation of $\alpha$-aminoisobutyric acid transport. J. Biol. Chem. 247: 6919-6926.

17. Blecher, M., and S. Goldstein. 1977. Hormone receptors: VI. On the nature of the binding of glucagon and insulin to human circulating mononuclear leukocytes. Mol. Cell Endocr. 8: 301-315.

18. Archer, J. A., P. Gorden, J. R. Gavin, III, M. A. Lesniak, and J. Roth. 1973. Insulin receptors in human circulating lymphocytes: application to the study of insulin resistance in man. J. Clin. Endocrinol. Metab. 36: 627-632.

19. Antoniolo, J. A., J. P. Felber, and A. Vannotti. 1967. Effect de l'insuline et de quelques autres facteurs sur la glycolyse des leucocytes humaines mesure'e in vitro. Acta Haematol. 37: 161-173.

20. Bar, R. S., L. C. Harrison, M. Muggeo, P. Gorden, C. R. Kahn, and J. Roth. 1979. Regulation of insulin receptors in normal and abnormal physiology in humans. In Advances In Internal Medicine. G. H. Stollerman, editor. Year Book Medical Publishers, Chicago, Ill.

21. Reeves, J. P. 1975. Stimulation of 3-O-methylglucose transport by anaerobiosis in rat thymocytes.J. Biol. Chem. 250: 9413-9420.

22. Reeves, J. P. 1977. 3-O-methylglucose transport by rat thymocyte subpopulations. J. Cell. Physiol. 92: 309-318.

23. Yasmeen, D., A. J. Laird, D. A. Hume, and M. J. Weidemann. 1977. Activation of 3-O-methyl-glucose transport in rat thymus lymphocytes by concanavalin A. Biochim. Biophys. Acta. 500: 89-102.

24. Peters, J. H., and P. Hausen. 1971. Effect of phytohemagglutinin on lymphocyte membrane transport. Eur. J. Biochem. 19: 509-513.

25. Culvenor, J. G., and M. J. Weidemann. 1976. Phytohaemagglutinin stimulation of rat thymus lymphocyte glycolysis. Biochim. Biophys. Acta. 437: 354-363.

26. Hedeskov, C. J. 1968. Early effects of phytohaemagglutinin on glucose metabolism of normal human lymphocytes. Biochem. J. 110: 373-380.

27. Hadden, J. W., E. M. Hadden, E. E. Wilson, R. A. Good, and R. G. Coffey. 1972. Direct action of insulin on plasma membrane ATPase activity in human lymphocytes. Nat. New Biol. 235: 174-176.

28. Helmreich, E., and H. N. Eisen. 1959. The distribution and utilization of glucose in isolated lymph node cells. J. Biol. Chem. 234: 1958-1965.

29. Munck, A. 1971. Glucocorticoid inhibition of glucose uptake by peripheral tissues: old and new evidence, molecular mechanisms, and physiological significance. Perspect. Biol. Med. 14: 265-289.

30. Hofert, J. F., and K. J. Phillips. 1978. In vitro insulinstimulated conversion of $\left[\mathrm{U}^{-14} \mathrm{C}\right] \mathrm{glucose}$ to ${ }^{14} \mathrm{CO}_{2}$ by rat thymocytes. Endocrinology. 102: 751-756.

31. Hollenberg, M. D., and P. Cuatrecasas. 1973. Epidermal growth factor: receptors in human fibroblasts and modulation of action by cholera toxin. Proc. Natl. Acad. Sci. U. S. A. 70: 2964-2968.

32. Katz, J., and H. G. Wood. 1963. The use of ${ }^{14} \mathrm{CO}_{2}$ yields from glucose- 1 - and $6-{ }^{14} \mathrm{C}$ for the evaluation of the pathways of glucose metabolism. J. Biol. Chem. 238: 517523.

33. Mendelsohn, J., A. Skinner, and S. Kornfeld. 1971. The rapid induction by phytohemagglutinin of increased $\alpha$-aminoisobutyric acid uptake by lymphocytes. J. Clin. Invest. 50: 818-826.

34. Strom, T. B., M-A. Lane, and J. H. Helderman. 1978. Immunoregulation by hormones and neurotransmitters. In Proceedings of the XIIth International Congress of Nephrology. S. Karger, Basel, Switzerland. 585-587.

35. Helderman, J. H., T. B. Strom, and A. Dupuy D'Angeac. 1979. A close relationship between cytotoxic T lymphocytes generated in the mixed lymphocyte culture and insulin receptor-bearing lymphocytes: enrichment by density gradient centrifugation. Cell. Immunol. 46: 247-258. 